\title{
Trace metals in molluses from the Beagle Channel (Argentina): a preliminary study
}

\author{
M. E. Conti ${ }^{1}$, J. Stripeikis ${ }^{2}$, M. Iacobucci ${ }^{3}$, D. Cucina ${ }^{1}$, \\ G. Cecchetti ${ }^{3} \&$ M. B. Tudino ${ }^{2}$ \\ ${ }^{I}$ Dipartimento di Controllo e Gestione delle Merci e del loro Impatto \\ sull'Ambiente, Facoltà di Economia, Università "La Sapienza", Roma, \\ Italy \\ ${ }^{2}$ INQUIMAE, Departamento de Química Inorgánica, Analítica y Química \\ Física, Facultad de Ciencias Exactas y Naturales, \\ Universidad de Buenos Aires, Buenos Aires, Argentina \\ ${ }^{3}$ Centro per le Valutazioni Ambientali delle Attività Industriali, \\ Facoltà di Scienze Ambientali, Università degli Studi di Urbino, Urbino, \\ Italy
}

\begin{abstract}
Individuals of Mytilus chiloensis (Hupè, 1854) and Nacella magellanica metalica (Rochebrune and Mabille, 1885) were evaluated as possible biomonitors of trace metal baseline contamination in the Beagle Channel, Tierra de Fuego (Argentina). The selected species have the necessary prerequisites for use as biomonitors. They are well distributed in all coastal areas of the Beagle Channel and other regional seas, they are easy to identify and available all year round.

The first aim of this preliminary survey is to evaluate the concentrations of $\mathrm{Cr}, \mathrm{Cu}, \mathrm{Pb}$ and $\mathrm{Zn}$ present in soft tissues of the selected species in order to have more information on the use of these selected species as possible cosmopolitan biomonitors. Samples were collected in seven stations situated along $170 \mathrm{~km}$ of the coast in the tidal zone. The validity of these two species as bioaccumulators was tested.
\end{abstract}

Significant differences between metal concentrations in molluscs from different stations were tested by ANCOVA on $\log _{10}$ transformed data with body weight as covariate. Multiple comparison tests (MCT) were conducted when significant differences were detected among the stations.

In M. chiloensis metal concentrations decreased in the order: $\mathrm{Zn}>\mathrm{Cu}>\mathrm{Pb} \geq$ $\mathrm{Cr}$ while for Nacella metal concentrations decreased in the order: $\mathrm{Zn}>\mathrm{Cu}>\mathrm{Cr}>$ $\mathrm{Pb}$ showing good bioaccumulation ability. At present, they can be considered as good candidates as trace metals biomonitors for the studied area.

From all the obtained data and statistical analysis (ANCOVA, MCT) the results showed clearly that there is no one site univocally more contaminated (with clearly high levels of metals accumulation in biomonitors) than any other. Thus the possible hypothesis of the Ushuaia Harbour as being the most contaminated site must be reconsidered. Metal concentrations recorded may be used for background levels for intraspecific comparison within the Patagonian seas. 


\section{Introduction}

The use of biological species in the monitoring of trace metals in coastal areas allows evaluating the contaminants bioavailability or the effects of contaminants on marine organisms. Molluscs are among the organisms most used as bioindicators for trace metal pollution in biomonitoring programmes. Limpets and particularly bivalve molluscs can accumulate and integrate concentrations of several metals in seawater for relatively long intervals. They also assimilate trace metals from their food and from the ingestion of inorganic particulate material [1-4]. The levels of heavy metals accumulated by marine organisms are also a function of many factors such as temperature, salinity, diet, spawning, seasonal variations [5] and can also constitute a potential hazard for humans and other mammals. This is because some molluses and limpets constitute a seafood group of particular interest.

The main advantage of the biomonitoring approach is a remarkable reduction in time and costs, consumed in frequent analyses of abiotic matrices of water and sediment samples. Bioaccumulators must have necessary requirements: they must be cosmopolitan and available all year round; they must accumulate the pollutant without being killed by the levels it comes in touch with; they must present a high concentration value of the contaminant and must be easy to sample and to preserve. Above all they must have a contaminant concentration that could be easily correlated with the concentration in the surrounding environment [5-7]. Mussels filter the surrounding water and they constantly accumulate metals in their tissues. Besides, they are easy to collect and to identify. Mytilus chiloensis (Hupè, 1854) is well distributed in South American seas (i.e. Beagle Channel, Strait of Magallanes, etc.); also a limpet Nacella magellanica metalica (Rochebrune \& Mabille, 1885) is very abundant and it constitutes a good candidate as a possible biomonitor of trace metals in seawater. It lives on rocky substrata of tidelands at relatively shallow depths and tolerates fairly long periods of time outside of water. It eats algae and vegetable deposits that it scratches from the rocks. Moreover, it is important to underline that this herbivorous gastropod generally takes metals principally from the diet [8]. These molluscs are also relevant from the nutritional point of view. In fact they constitute a popular food in the studied areas.

The aim of the preliminary present study was to have more information on the use of these selected species as possible cosmopolitan biomonitors of $\mathrm{Cr}, \mathrm{Pb}, \mathrm{Cu}$ and $\mathrm{Zn}$ present in the Beagle Channel sea ecosystem.

\section{Materials and methods}

Beagle Channel is a strait in Tierra del Fuego, near the southern tip of South America. The channel has high ecological relevance and is about $240 \mathrm{~km}$ in length and between 5 and $14 \mathrm{~km}$ wide. It separates Isla Grande de Tierra del Fuego from several smaller islands to the south. The Beagle Channel was named for the British ship Beagle, in which Charles Darwin explored the area (1833-34). 


\section{Sampling stations}

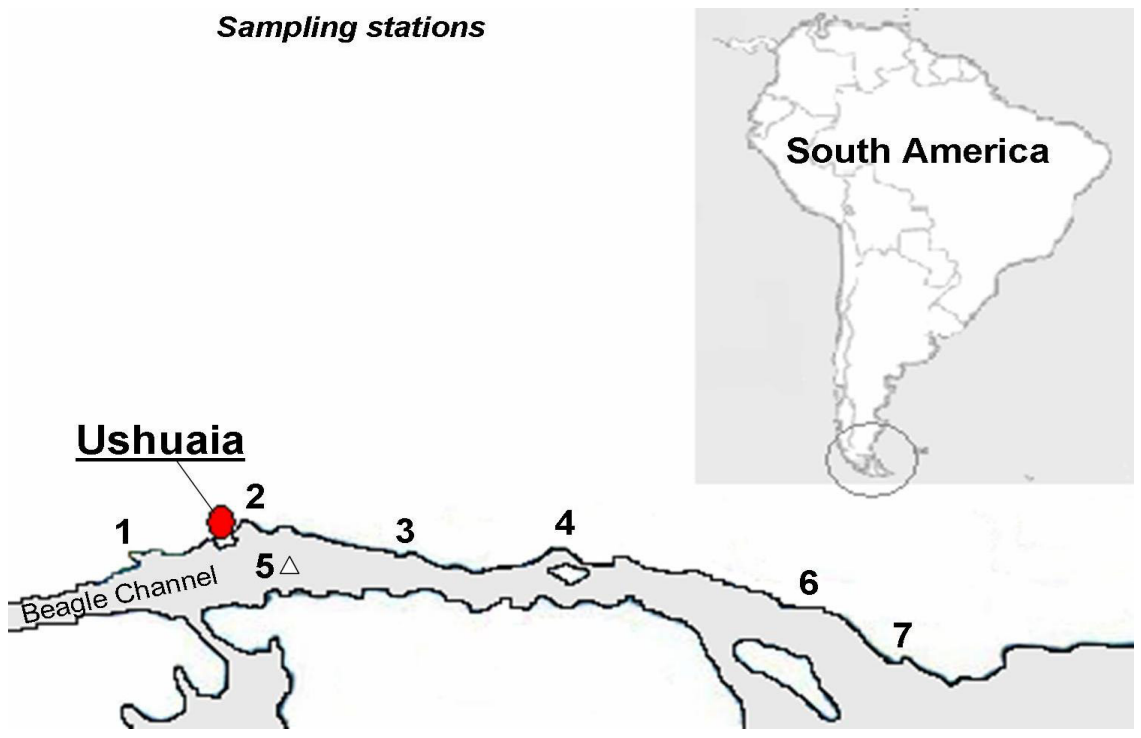

Figure 1: $\quad$ Sampling stations: 1) Lapataia Bay, 2) Ushuaia Harbour, 3) Punta Paranà, 4) Brown Bay, 5) Bridges Island, 6) Este Bay, 7) Punta Moat.

The molluscs have been sampled in February 2005 in 7 stations situated along of $170 \mathrm{~km}$ of the coast of the Beagle Channel (figure 1).

Individuals of Mytilus chiloensis (Hupè, 1854) $(\mathrm{n}=202)$ and Nacella magellanica metalica (Rochebrune \& Mabille, 1885) $(\mathrm{n}=105)$ have been picked in the tidal zone; then they were immersed $(t=24$ hours $)$ in filtered seawater to be purified.

Subsequently, the soft parts were taken out of the shell using tools (hammer and spatula) made exclusively of plastics, so as to prevent metal contamination, and then they were rinsed with deionized MilliQ water, in order to remove every residue of shell. Samples were placed in polyethylene bags, ice deep-frozen and transported to the laboratory.

Each sample of the mollusc previously homogenized $(400-800 \mathrm{mg}$ ) was treated with $8 \mathrm{ml}$ of $70 \%(\mathrm{w} / \mathrm{w})$ nitric acid Suprapur (Merck) and $2 \mathrm{ml}$ of $30 \%$ (w/w) hydrogen peroxide Suprapur (Merck) in PTFE vessels. The microwave digestion system MDS-2000 provided by CEM was used for the mineralization process.

Heavy metals in mollusc species were determined using a Shimadzu 6800 Atomic Absorption Spectrometer coupled to different atomic vapors generators depending on the analytical concentration. A graphite furnace accessory GFA6000 and an autosampler ASC-6000 was employed for $\mathrm{Pb}$ and $\mathrm{Cr}$ measurements and an air/acetylene flame was used for $\mathrm{Zn}$ and $\mathrm{Cu}$ determinations.

The calculation of dry weight (d.w.) on the studied species (10 replicates for each location) was carried out through oven drying at $105^{\circ} \mathrm{C}$ until constant weight was achieved. 
Traceability of results was obtained from the analysis of the certified reference material Antartic krill MURST-ISS-A2 (Italian Research Programme in Antartica). The mean recovery percentages (five replicates) were: $\mathrm{Cr}=$ $98.1 \pm 1.0 \% ; \mathrm{Cu}=101.1 \pm 1.3 \% ; \mathrm{Pb}: 96.5 \pm 0.6 \%$ and $\mathrm{Zn}: 102.1 \pm 2.9 \%$.

The detection limits (LODs) based on three times the standard deviation of the blank ( $\mathrm{n}=11$ ) were: $\mathrm{Cr}=0.0002 \mathrm{mg} . \mathrm{L}^{-1} ; \mathrm{Cu}=0.020 \mathrm{mg} . \mathrm{L}^{-1} ; \mathrm{Pb}=0.001 \mathrm{mg} . \mathrm{L}^{-}$ ${ }^{1}$ and $\mathrm{Zn}=0.010 \mathrm{mg} . \mathrm{L}^{-1}$.

Significant differences between metal concentrations in molluscs from different stations were tested by ANCOVA on $\log _{10}$ transformed data with body weight as covariate. Multiple comparison tests were conducted when significant differences were detected among the stations. SPSS 13.0 software was used for statistical analysis.

\section{Results}

Table 1 shows mean metal concentrations obtained by the analyses of the molluscs. Mean levels in biota are referred to dry weight to reduce variability of measurements determined by habitat, life conditions, pre-treatment and conservation of organisms after sampling [5].

In M. chiloensis metal concentrations decreased in the following order: $\mathrm{Zn}>$ $\mathrm{Cu}>\mathrm{Pb} \geq \mathrm{Cr}$. For M. chiloensis the values obtained were in the range of 57.91$111.54 \mu \mathrm{g} \mathrm{g}^{-1} \mathrm{dw}$ for $\mathrm{Zn}$; 3.90-7.41 $\mu \mathrm{g} \mathrm{g}^{-1} \mathrm{dw}$ for $\mathrm{Cu}$; $0.21-0.76 \mu \mathrm{g} \mathrm{g}^{-1} \mathrm{dw}$ for $\mathrm{Pb}$ and $0.26-0.98 \mu \mathrm{g} \mathrm{g}^{-1} \mathrm{dw}$ for Cr. Very few data are available on M. chiloensis.

Mean $\mathrm{Cu}$ and $\mathrm{Zn}$ levels determined in the Beagle Channel $\left(5.78 \mu \mathrm{g} \mathrm{g}^{-1} \mathrm{dw}\right.$ and $80.64 \mu \mathrm{g} \mathrm{g}^{-1} \mathrm{dw}$ respectively, see table 1) for M. chiloensis were higher with respect to those obtained for Strait of Magallanes (Chile) [9]. The comparison with the only other available dated study [10] was not possible because wet/dry weight ratio for $M$. chiloensis is not reported. We think that reporting data referred to dry weight basis is of paramount importance because this procedure can avoid high variability in the obtained data. However, if we compare our bivalves data with other Mytilus species from Mediterranean seas [1], in areas with low-medium contamination levels, we observe significantly $(p=0.05)$ lower mean values for $\mathrm{Cr}, \mathrm{Cu}, \mathrm{Pb}$ and $\mathrm{Zn}$ in the Beagle Channel.

For Nacella the values obtained were in the range of $62,12-76.15 \mu \mathrm{g} \mathrm{g}^{-1} \mathrm{dw}$ for $\mathrm{Zn}$; 6.77-11.87 $\mu \mathrm{g} \mathrm{g}^{-1} \mathrm{dw}$ for $\mathrm{Cu}$; $0.66-2.48 \mu \mathrm{g} \mathrm{g}^{-1} \mathrm{dw}$ for $\mathrm{Cr}$ and $0.11-2.13 \mu \mathrm{g}$ $\mathrm{g}^{-1} \mathrm{dw}$ for $\mathrm{Pb}$. As to Nacella metal concentrations decreased in the order: $\mathrm{Zn}>$ $\mathrm{Cu}>\mathrm{Cr}>\mathrm{Pb}$. Mean $\mathrm{Pb}$ levels for Nacella were clearly lower than $\mathrm{Cr}$ while for M. chiloensis the mean accumulation levels of $\mathrm{Cr}$ and $\mathrm{Pb}$ were very similar.

No data are available in the literature for metal accumulation in $N$. magellanica metalica. However, if we compare our results with data relative to other Nacella species collected in Magallanes Strait [9] we observe that our mean values $(p=0.05)$ for $\mathrm{Cu}$ and $\mathrm{Zn}$ have higher levels. Comparing also mean accumulation data from this study with other patellid limpet from Mediterranean sea $(P$. caerulea) [1], mean levels of $\mathrm{Cu}$ and $\mathrm{Zn}$ obtained were significantly lower $(p=0.05)$ in Nacella samples from the B. Channel.

To assess the existence of significant differences in the metal concentrations in molluscs, use of ANCOVA on $\log _{10}$ transformed data with body weight as 
covariate was taken into account. This approach was chosen because the high variability on individual weights of the collected samples. For Mytilus, normality and homoscedasticity were checked, and resulted to be substantially improved by the $\log$ transformation with the exception of $\mathrm{Pb}$ values.

Table 1: $\quad$ Concentrations of metals ( $\mu \mathrm{g} \mathrm{g}^{-1}$ dry weight) in the soft tissues of Mytilus chiloensis and Nacella magellanica metalica, (mean \pm s.d.).

\begin{tabular}{|c|c|c|c|c|c|}
\hline $\begin{array}{c}\text { Sampling } \\
\text { station } \\
\end{array}$ & Individuals & $\mathrm{Cr}$ & $\mathrm{Cu}$ & $\mathbf{P b}$ & Zn \\
\hline \multicolumn{6}{|c|}{ Mytilus chiloensis } \\
\hline 1 & 30 & $0.28 \pm 0.15$ & $6.82 \pm 2.49$ & $0.35 \pm 0.27$ & $57.91 \pm 14.28$ \\
\hline 2 & 30 & $0.27 \pm 0.13$ & $5.46 \pm 1.74$ & $0.76 \pm 0.66$ & $94.14 \pm 50.79$ \\
\hline 3 & 30 & $0.26 \pm 0.35$ & $4.94 \pm 1.95$ & $0.23 \pm 0.19$ & $72.51 \pm 45.23$ \\
\hline 4 & 30 & $0.27 \pm 0.15$ & $5.98 \pm 1.75$ & $0.41 \pm 0.39$ & $111.54 \pm 82.16$ \\
\hline 5 & 30 & $0.43 \pm 0.27$ & $7.41 \pm 2.00$ & $0.21 \pm 0.16$ & $77.64 \pm 54.49$ \\
\hline 6 & 30 & $0.50 \pm 0.27$ & $5.47 \pm 1.49$ & $0.59 \pm 0.37$ & $85.67 \pm 61.17$ \\
\hline 7 & 22 & $0.98 \pm 0.38$ & $3.90 \pm 1.62$ & $0.47 \pm 0.44$ & $59.36 \pm 23.15$ \\
\hline $\begin{array}{l}\text { Total / } \\
\text { Mean }\end{array}$ & 202 & $0.41 \pm 0.33$ & $5.78 \pm 2.14$ & $0.43 \pm 0.42$ & $80.64 \pm 58.83$ \\
\hline \multicolumn{6}{|c|}{ Nacella magellanica metalica } \\
\hline 1 & 15 & $2.38 \pm 0.97$ & $11.87 \pm 5.82$ & $1.49 \pm 0.48$ & $76.15 \pm 11,16$ \\
\hline 2 & 15 & $2.48 \pm 1.02$ & $10.04 \pm 4.70$ & $2.13 \pm 1.03$ & $74.38 \pm 12.00$ \\
\hline 3 & 15 & $1.04 \pm 0.97$ & $8.11 \pm 2.85$ & $0.65 \pm 0.25$ & $66.58 \pm 8.54$ \\
\hline 4 & 15 & $1.48 \pm 0.79$ & $8.20 \pm 3.41$ & $0.11 \pm 0.02$ & $67.84 \pm 7.75$ \\
\hline 5 & 15 & $0.66 \pm 0.47$ & $7.48 \pm 2.37$ & $0.47 \pm 0.25$ & $62.12 \pm 8.62$ \\
\hline 6 & 15 & $1.91 \pm 1.66$ & $10.32 \pm 4.57$ & $0.41 \pm 0.33$ & $70.18 \pm 13.55$ \\
\hline 7 & 15 & $1.66 \pm 0.79$ & $6.77 \pm 1.82$ & $0.43 \pm 0.21$ & $63.86 \pm 6.74$ \\
\hline $\begin{array}{l}\text { Total / } \\
\text { Mean }\end{array}$ & 105 & $1.66 \pm 1.16$ & $8.97 \pm 4.13$ & $0.81 \pm 0.82$ & $68.73 \pm 10.87$ \\
\hline
\end{tabular}

Fresh/dry weight ratio: 3,54 (Mytilus) and 4,88 (Nacella).

Parallelism of the regression lines between all sites was tested throughout at a $p$ level of 0.05 . For $\mathrm{Cr}$ and $\mathrm{Zn}$ (M. chiloensis) the condition of parallelism of the regression lines was met $(\mathrm{F}=0.865$, sig. $=0.522$ for $\mathrm{Cr}$; and $\mathrm{F}=0.339$, sig. $=0.915$ for $\mathrm{Zn}$ ), then ANCOVA was performed. Results showed significant differences in $\mathrm{Cr}$ and $\mathrm{Zn}$ concentrations in $M$. chiloensis between the studied sites (Tables 2-3). 
Table 2: $\quad$ ANCOVA test for Cr between sites (M. chiloensis).

\begin{tabular}{|l|r|r|r|r|r|}
\hline Source & \multicolumn{1}{|c|}{$\begin{array}{c}\text { Type III Sum of } \\
\text { Squares }\end{array}$} & df & Mean Square & F & Sig. \\
\hline Corrected & $9,224(\mathrm{a})$ & 7 & 1,318 & 19,204 &, 000 \\
Model & 3,503 & 1 & 3,503 & 51,053 &, 000 \\
Intercept &, 503 & 1 &, 503 & 7,330 &, 007 \\
Weight & 4,665 & 6 &, 778 & 11,332 &, 000 \\
Site & 13,311 & 194 &, 069 & & \\
Error & 75,548 & 202 & & & \\
Total & 22,535 & 201 & & & \\
Corrected & & & & \\
Total & & & & \\
\hline
\end{tabular}

Table 3: $\quad$ ANCOVA test for $\mathrm{Zn}$ between sites (M. chiloensis).

\begin{tabular}{|l|r|r|r|r|r|}
\hline Source & $\begin{array}{c}\text { Type III Sum of } \\
\text { Squares }\end{array}$ & df & Mean Square & F & Sig. \\
\hline Corrected & $1,337(\mathrm{a})$ & 7 &, 191 & 4,211 &, 000 \\
Model & 95,387 & 1 & 95,387 & 2102,25 &, 000 \\
Intercept &, 147 & 1 &, 147 & 3,240 &, 073 \\
Weight Total & 1,261 & 6 &, 210 & 4,630 &, 000 \\
Site & 8,802 & 194 &, 045 & & \\
Error & 694,189 & 202 & & & \\
Total & 10,140 & 201 & & & \\
Corrected & & & & \\
Total & & & & \\
\hline
\end{tabular}

For $\mathrm{Cu}$ (M. chiloensis) the parallelism condition was not met $(\mathrm{F}=3.405$, sig $=0.003$ ) and then ANCOVA was not performed. From the valuation of different regression models (logarithmic, exponential, polynomial, etc.) resulted that $\mathrm{Cu}$ depends slightly from weight. Then, analysis of variance (ANOVA) was performed. ANOVA results showed that significant differences are present between sites for $\mathrm{Cu}$ accumulation in Mytilus.

The tests of normality and homoscedasticity for $\mathrm{Pb}$ resulted to be not improved by the log transformation. For this reason, a non-parametric KruskalWallis test was conducted. Results showed significant differences for mean $\mathrm{Pb}$ concentrations in M. chiloensis between the studied sites (Table 4).

Multiple comparison tests (MCT) were conducted for $\mathrm{Cr}, \mathrm{Cu}$ and $\mathrm{Zn}$ (Tukey HSD; Bonferroni; Tamhane; Dunnett T3 and Scheffè) and non-parametric MCT were also conducted for $\mathrm{Pb}$ (Games-Howell, Dunnett's C, Tamhane's T2) in order to know which station is more contaminated than another. 
Table 4: $\quad$ Kruskal-Wallis test for $\mathrm{Pb}$ between sites (M. chiloensis).

\begin{tabular}{|l|r|}
\hline & \multicolumn{1}{|c|}{$\log \mathrm{Pb}$} \\
\hline Chi-Square & 42,214 \\
\hline df & 6 \\
\hline Asymp. Sig. &, 000 \\
\hline
\end{tabular}

Results for $\mathrm{Cr}$ (M. chiloensis) showed that site 7 (Punta Moat) has mean values significantly higher $\left(0.98 \mu \mathrm{g} \mathrm{g}^{-1} \mathrm{dw} ; p=0.05\right)$ than the all other sites. The sites 5 (Bridges islands) and 6 (Este Bay) have similar $\mathrm{Cr}$ mean values and significantly higher than sites 1 (Lapataia Bay), 2 (U. Harbour) and 3 (Punta Paraná) and 4 (Brown Bay) but significantly lower than the site 7.

MCT conducted for $\mathrm{Cu}$ in $M$. chiloensis showed that site 7 (P. Moat) has lower mean $\mathrm{Cu}$ levels than the others with the exception of site 3 (P. Paraná) that has similar levels of site 7 .

MCT conducted for $\mathrm{Zn}$ in M. chiloensis showed that sites 2 (U. Harbour) and 4 (Brown Bay) have mean Zn values significantly higher than the all other sites. Sites 1 (Lapataia) and 7 (P. Moat) have mean $\mathrm{Zn}$ concentrations lower than sites 2 and 4.

MCT conducted for $\mathrm{Pb}$ showed that sites 2 (U. Harbour) and 6 (Este Bay) has significantly higher mean $\mathrm{Pb}$ concentrations than the others with the exception of site 7 that showed average levels of $\mathrm{Pb}$.

For Nacella normality and homoscedasticity were checked and resulted to be clearly improved by the log transformation for all metals. The same ANCOVA model was employed. Parallelism of the regression lines between all sites was tested and the condition of parallelism of the regression lines was met for all metals. Then, it was possible to use ANCOVA for testing differences in mean metal concentrations between sites.

Results of ANCOVA showed that there are no significantly differences between mean $\mathrm{Zn}$ and $\mathrm{Cu}$ concentrations for Nacella between the selected sites. Besides, ANCOVA showed significantly differences between almost a couple of sites for $\mathrm{Cr}$ and $\mathrm{Pb}$ for Nacella species. Then, MCT were conducted for these metals.

MCT conducted for $\mathrm{Cr}$ in Nacella showed that sites 1 (Lapataia Bay) and 2 (U. Harbour) have the higher Cr levels; the sites 4 (B. Brown), 6 (E. Bay) and 7 (P. Moat) have average Cr levels; the sites 3 (P. Paraná) and 5 (Bridges islands) showed lower Cr levels.

MCT for $\mathrm{Pb}$ in Nacella showed that site 4 (Brown Bay) has mean $\mathrm{Pb}$ concentrations significantly lower than the other sites. The sites 3 (P. Paraná), 5 (Bridges Islands), 6 (Este Bay) and 7 (P. Moat) have similar $\mathrm{Pb}$ levels and significantly lower than sites 1 (Lapataia Bay) and 2 (U. Harbor). The sites 1 and 2 presented the higher $\mathrm{Pb}$ levels.

In conclusion, from the reported statistical analysis we can observe that there is no one site more univocally contaminated than another for the studied trace metals in the selected biomonitors. 
We have also tested the bioaccumulation ability of $M$. chiloensis and Nacella by using the $t$-student test (Table 5).

This study confirms that Nacella has clearly high bioaccumulation levels of $\mathrm{Cr}, \mathrm{Cu}, \mathrm{Pb}$ and $\mathrm{Zn}$ than Mytilus (figures 2-5).

Table 5: $\quad t$-student test for all metals. Equal variances not assumed.

\begin{tabular}{|l|r|c|r|c|}
\hline Variable & $t$-student & $\mathrm{df}$ & Sig. (2-tailed) & $\begin{array}{c}\text { Mean } \\
\text { Difference }\end{array}$ \\
\hline $\mathrm{Cr}$ & $-10,818$ & 112,701 &, 000 & $-1,2525163$ \\
\hline $\mathrm{Cu}$ & $-7,407$ & 133,711 &, 000 & $-3,1885070$ \\
\hline $\mathrm{Pb}$ & $-4,488$ & 133,744 &, 000 &,- 3811073 \\
\hline $\mathrm{Zn}$ & 2,976 & 230,020 &, 003 & 11,9064298 \\
\hline
\end{tabular}

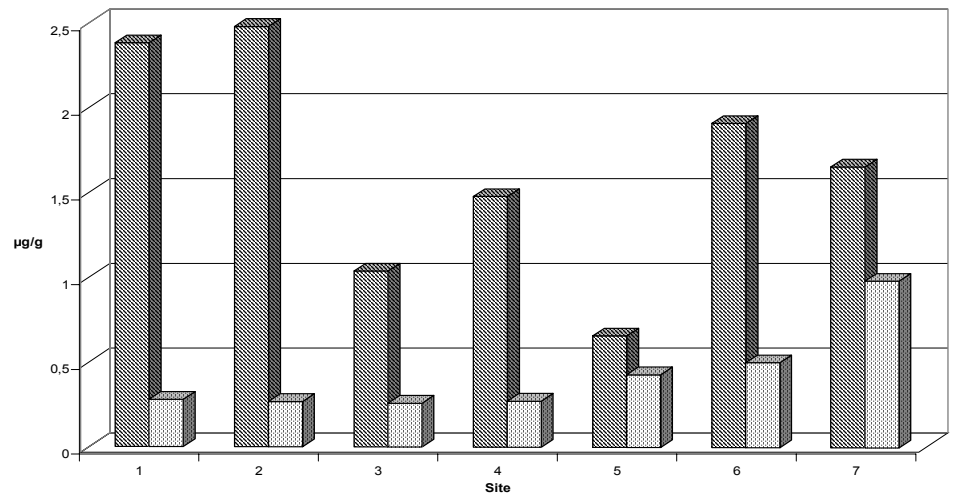

R Nacella magellanica m. [Mytilus chiloensis

Figure 2: $\quad$ Cr concentrations in Mytilus and Nacella in the selected sites.

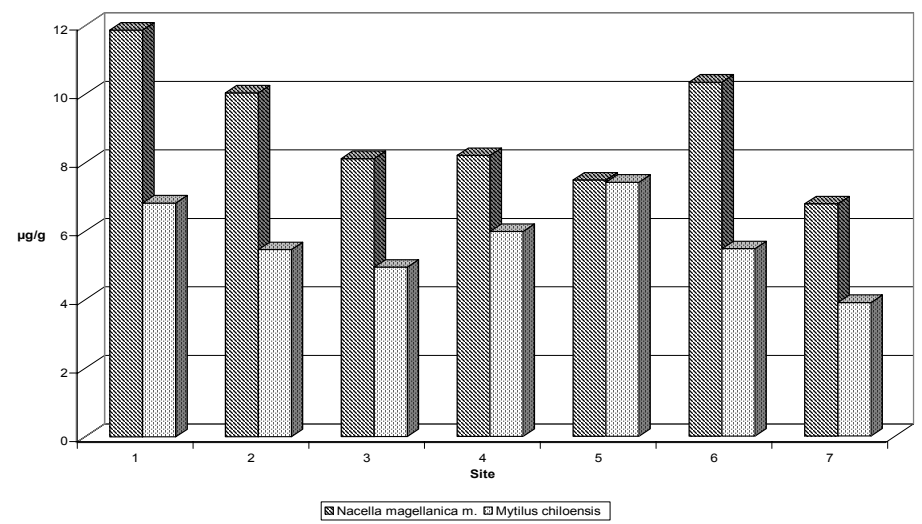

Figure 3: $\mathrm{Cu}$ concentrations in Mytilus and Nacella in the selected sites. 


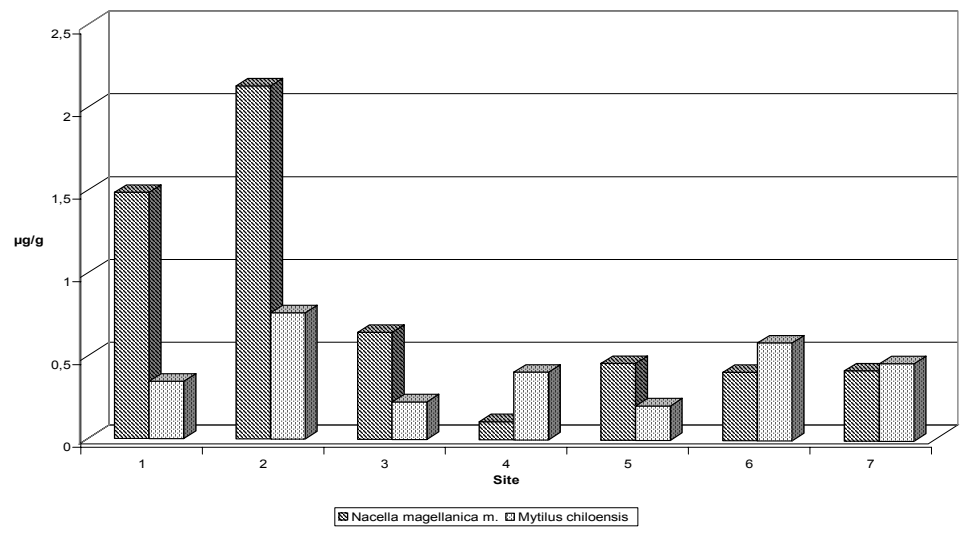

Figure 4: $\quad \mathrm{Pb}$ concentrations in Mytilus and Nacella in the selected sites.

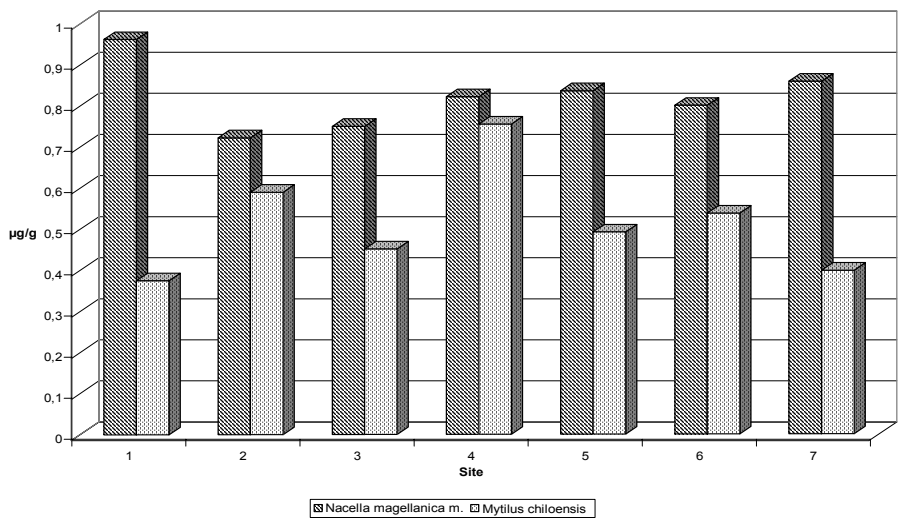

Figure 5: $\quad$ Zn concentrations in Mytilus and Nacella in the selected sites.

\section{Conclusions}

The use of the selected species turned out to be very valuable for the study of a coastal area with low levels of contamination. Then, M. chiloensis and $N$. magellanica metalica can be considered as potential biomonitors of trace metal pollution in the considered geographical areas. The selected biomonitors showed a very good ability to concentrate trace metals from seawater.

These two mollusc species have the necessary requisites: they are easy to identify and capture, they are sessile and sedentary, they are available all year round, and they are present along all coasts of the Beagle Channel.

Comparing our data with those available for M. chiloensis from the Magallanes Strait [9], the Beagle Channel bivalves showed higher $\mathrm{Cu}$ and $\mathrm{Zn}$ levels. However, this values are significantly lower $(p=0.05)$ than those of other Mytilus species from Mediterranean areas [1]. Comparing also our data with 
those available for other patellid limpets, our $\mathrm{Cu}$ and $\mathrm{Zn}$ accumulation levels for Nacella magellanica metalica were comparable to those of the Magellan Strait [9] and significantly lower than samples of Mediterranean areas [1].

Statistical analysis for Mytilus revealed that, as far as $\mathrm{Cr}$ is concerned, Punta Moat station presents higher $\mathrm{Cr}$ concentrations than the other sites. On the other hand the same site shows, with some exception, lower levels of $\mathrm{Cu}$. Ushuaia Harbour and Brown Bay have $\mathrm{Zn}$ values significantly higher than all the other sites. $\mathrm{Pb}$ accumulation values for Mytilus showed that U. Harbour and Este Bay sites have, with some exception, higher $\mathrm{Pb}$ concentrations than the others.

By using Nacella, results showed that there are no significantly differences for $\mathrm{Zn}$ and $\mathrm{Cu}$ concentrations between the selected sites.

The $\mathrm{Cr}$ accumulation levels in Nacella were significantly higher in Lapataia Bay and Ushuaia Harbour. Punta Paraná and Bridges islands resulted with a lower $\mathrm{Cr}$ levels. The $\mathrm{Pb}$ accumulation levels for Nacella showed that Brown Bay has mean $\mathrm{Pb}$ concentrations significantly lower than the other sites. Lapataia and $\mathrm{U}$. Harbour resulted with the highest $\mathrm{Pb}$ levels.

From the reported data and statistical analysis, it is clear that there is no one site univocally more contaminated (with clearly high levels of metals accumulation in biomonitors) than another. Thus, the possible hypothesis of the Harbour as being the most contaminated site must be reconsidered.

The follow-up of this study, extended to other biomonitors and contaminants along time and including metal determination in surrounding seawater, might further confirm these first results.

\section{References}

[1] Conti, M.E. \& Cecchetti, G., A biomonitoring study: trace metals in algae and molluscs from Tyrrhenian coastal areas. Environmental Research, 93, pp. 99-112, 2003.

[2] Phillips, D. \& Segar, D. A., Use of bio-indicators in monitoring conservative contaminants: programme design imperatives. Marine Pollution Bulletin, 26, pp. 593-601, 1986.

[3] Campanella, L., Conti, M.E., Cubadda, F. \& Sucapane, C., Trace metals in seagrass, algae and molluscs from an uncontaminated area in the Mediterranean. Environmental Pollution, 111, pp. 117-126, 2001.

[4] Conti, M.E., Iacobucci, M. \& Cecchetti, G., The biomonitoring approach as a tool of trace metal assessment in an uncontaminated marine ecosystem: Ustica island (Sicily, Italy), in: Geo-Environment, Monitoring, Simulation and Remediation of the Geological Environment; J.F. MartinDuque, C.A. Brebbia, A.E. Godfrey, J.R. Dìaz de Teràn (Eds.), WIT Press, 335-344, 2004.

[5] Conti, M.E., Il monitoraggio biologico della qualità ambientale, ed. SEAM: Roma, pp. 35-38, 2002.

[6] Conti, M.E. \& Cecchetti, G., Biological Monitoring: lichens as bioindicators of air pollution assessment - a review. Environmental Pollution, 114, pp. 471-492, 2001. 
[7] Conti, M.E. , Iacobucci, M., Mecozzi, M., Cecchetti, G. (2006) Trace metals in soft tissues of two marine gastropod molluscs: Monodonta turbinata B. and Patella caerulea L. collected in a marine reference ecosystem, in: Environmental problems in coastal regions VI, including oil spill studies; C.A. Brebbia, (Ed.), WITpress, 3-11.

[8] Ahn, I.-Y., Kim, K.-W. \& Choi, H.J. A baseline study on metal concentrations in the Antarctic limpet Nacella concinna (Gastropoda: Patellidae) on King George Island: variations with sex and body parts, Marine Pollution Bulletin, 44, 421-431, 2002.

[9] Astorga España, M.S., Rodríguez Rodríguez, E.M. \& Díaz Romero, C., Sodium, $\mathrm{K}, \mathrm{Ca}, \mathrm{Mg}, \mathrm{Fe}, \mathrm{Cu}$, and $\mathrm{Zn}$ concentrations in molluscs from the Magellan Strait (Chile): their contribution to dietary intake, International Journal of Food Sciences and Nutrition, 56, 337-347, 2005.

[10] Astorga España, M.S., Peña Méndez, E.M., Lecaros Palma, O. \& García Montelongo, F.J., Heavy Metals in Mytilus chilensis from the Strait of Magallanes (Chile), Marine Pollution Bulletin, 36, 542-546, 1998. 